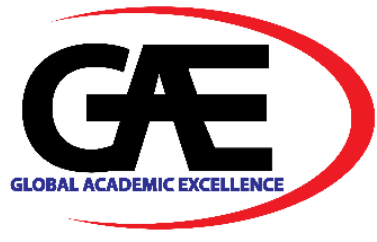

\title{
DETERMINANTS TO HOMEOWNERSHIP AND/OR LEASING INTENTIONS: A REVIEW AND PROPOSED FRAMEWORK
}

\author{
William Wee-Lim Hew ${ }^{1,3^{*}}$, Cheng Ling Tan ${ }^{2}$, Sook Fern $\mathrm{Yeo}^{3}$ \\ 1 Faculty of Business, Multimedia University, Melaka, Malaysia \\ Email: wlhew@mmu.edu.my \\ 2 Graduate School of Business, Universiti Sains Malaysia, Penang, Malaysia \\ 3 Faculty of Business, Multimedia University, Melaka, Malaysia \\ * Corresponding Author
}

\section{Article Info:}

\section{Article history:}

Received date: 13.07 .2020

Revised date: 10.08 .2020

Accepted date: 30.09 .2020

Published date: 01.12 .2020

\section{To cite this document:}

Hew, W. W. L., Tan, C. L., \& Yeo, S. F. (2020). Determinants to Homeownership and/or Leasing Intentions: A Review and Proposed Framework. International Journal of Law, Government and Communication, 5 (21), 22-33.

DOI: $10.35631 /$ IJLGC.521003.

This work is licensed under $\underline{\mathrm{CC} B Y} 4.0$

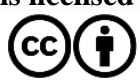

Abstract:

The contribution the housing and construction sector makes to the national economy is closely tied to new project launches in the country. At present, nations are suffering from a global economic slowdown and a slumping property market. Governments and private developers have even initiated many affordable housing projects, but interestingly these units are not as popular as expected. Many housing projects across the world are initiated without a clear understanding of the needs and behavioural tendencies of homebuyers. The ability to understand homebuyers' behaviour is limited due to the lack of sufficient research using a concise and all-encompassing framework that is supported by a strong theoretical foundation. A thorough review and comparison of three fields of psychology found environmental psychology to be suitable and Mehrabian and Russell's (1974) theory to be relevant, and ought to be complemented with the theory of planned behaviour (TPB). A framework is proposed, positing that favourable evaluations of the environment (residential environment) and social factors (attitude, subjective norms, perceived behavioural control) will elicit favourable emotional states (pleasure, arousal, dominance/place attachment) which in turn lead to favourable behavioural response (homeownership intention). On the other hand, should the evaluations of the environment and social factors be unfavourable, this would lead to unfavourable emotions and subsequently unfavourable behavioural response (leasing intention).

Keywords:

Homeownership, Home Purchase, Sustainable Housing 


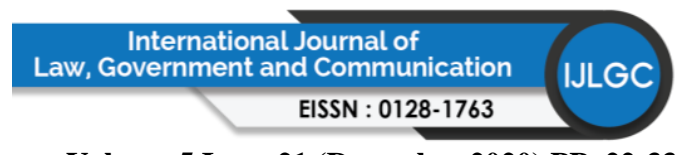

Volume 5 Issue 21 (December 2020) PP. 22-33 DOI 10.35631/IJLGC.521003

\section{Introduction}

Homeownership contributes to the economy in various ways. It has been credited for the creation of an urban middle class who has a large hand in running national economies (Lee, 2002; Ronald, 2007). They are also the largest group of taxpayers who makes up the lion share of government tax revenues (Gervais, 2002). Moreover, homeowners are the commercial banks' main source of income as banks depend on them to interest payments on bank mortgages. These payments create a pool of lending funds required to support expansion of businesses (DeYoung \& Rice, 2004).

In terms of societal contributions, homeownership promotes family stability. As families become stable, they tend to remain in the community as homeowners (Yun \& Evangelou, 2016). The decision to become a homeowner will then have a multiplier effect on their other economic-generating behaviours. For instance, homeowners, as stable residents, tend to expand their family size, and with that they have to consume more household products and services (Bourguignon et al., 1993). Homeowners also have greater sense of commitment towards their communities. Because of their inter-dependency with the community, they will be more willing to invest into maintenance of the area, and also be more socially cohesive with the local community. Through their close dealings with neighbours, they will also be able to supervise their children better and this will correct children behaviour and improve their academic performance (Tan, 2008).

Because of the various benefits that homeownership provides, national governments have always pursued homeownership for their citizens in national development blueprints. Nonetheless despite various efforts, low homeownership remained a perpetual problem in many countries and the conditions have become even more severe in the recent decade. Both the Government and private developers often cooperate in the offering of more affordable units, but these projects are not always effective. However, affordable homes are often not attractive to aspiring homeowners, even to the lower-income groups. Therefore, merely building more units without clear understanding of homebuyer motivations is not a sustainable approach to residential development.

A good framework is needed to explain the inner workings of why residents prefer homeownership or leasing as a housing tenure choice. This should be done using a framework that is supported by a strong theoretical foundation. Only from there may clear conclusions may be made and right corrective actions may be undertaken. Going back to the notion of sustainability, sustainable housing must be supported by the three pillars: (i) the houses must have economic relevance and valuable as a store of wealth, (ii) it must also have environmentally or ecological relevance, meaning it should be improving the quality of life of the residents through pleasant and rejuvenating environment, and (iii) it must have social relevance, conducive for human activities, or the neighbourhood that brings life to the area. Therefore, a framework that is in line with sustainable notions must be able to relate to all these three components.

At present, many empirical researches on homeownership have been employing a neo-classical approach whereby housing market performance through hard data and econometrics (e.g. Cohen et al., 2009; Lindblad et al., 2017). Neo-classical studies lack the social component that establish the human factor in behavioural research and is hence appropriate for generalising. Nonetheless, because the study of homeownership behaviour is at a micro level, it should be Copyright (C) GLOBAL ACADEMIC EXCELLENCE (M) SDN BHD - All rights reserved 


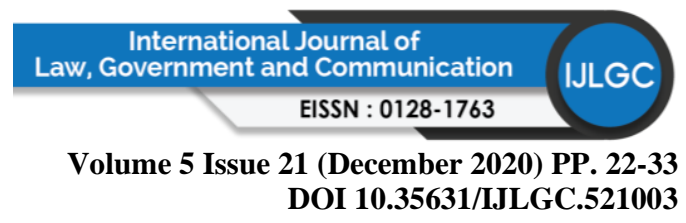

done from a psychological perspective (Boelhouwer, 2011; Marsh \& Gibb 2011; Rohe et al., 2013). Therefore, the aim of this paper is to critically review the relevant psychological theories that is relevant to studying homeownership behaviour, and to propose a sound framework that adequately explains the factors that influence a person's homeownership or leasing intention

\section{Literature Review}

There are three major branches of psychology that are relevant in studying homeownership behaviour, namely humanistic psychology, social psychology and environmental psychology. The following sub-sections review the various advantages and disadvantages of each of these fields in explaining homeownership behaviour.

\section{Homeownership from the Humanistic Psychology Perspective}

Humanistic psychology is a field of psychology that focuses on the innate nature of a person. Homeownership behaviour, from the viewpoint of humanistic psychology may be explained through Maslow's (1954) hierarchy of needs. According to the theory, every individual has five basic needs that need to be fulfilled, and these may be arranged in a hierarchy of importance, whereby the lower needs must be fulfilled before higher level needs can be realised. The five needs, from the lowest to the highest are: physiological needs, safety needs, social needs, esteem needs, and self-actualisation needs. Physiological needs are the basic necessities humans need to survive; safety need are the needs for a safe and secure environment that is free from harm; social needs are the needs of being part of a social circle where one is loved and cherished; esteem needs are the need to be valued and respected ; while self-actualisation need is the need to realise one's full potential as "what humans can be, they must be" (Maslow, 1954, p.22).

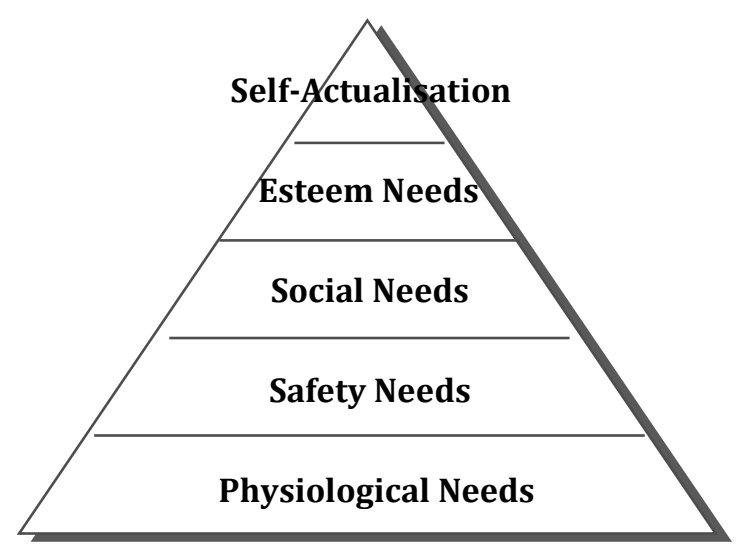

\section{Figure 1: Maslow Hierarchy of Needs}

Relating to homeownership, homeownership is traditionally regarded as a fulfilment of safety needs by providing a shelter from rain and shine and protection against criminals. Nonetheless, we may also look at homeownership at satisfying higher levels of need. For instance, homeownership also fulfils social needs, as it creates a safe space for family and friends to gather and socialise. It also fulfils esteem needs by giving an individual a sense of achievement in life and garnering respect (see Lindamood \& Hanna, 1979; Zavei \& Jusan, 2012; van Ham, 2012). 


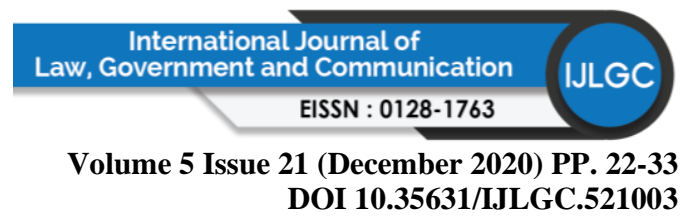

Although humanistic psychology appears to be relevant by explaining the various internal motivations of homeownership, its concepts are vague, difficult to measure, and loosely held together by Maslow's theory. Maslow's theory may provide some basic understanding on homeownership behaviour, it has since early days been criticised for the difficulty of operationalisation, which contributed to its lack of empirical verification (Kokoszka, 1991; Wahba \& Bridwell, 1976). Another issue that may rise is, the homeownership needs are different for people in different social background (van Ham, 2012). For instance, the poor may regard homeownership as more of a safety need while the socially affluent may regard it more of a testimony of his or her success and achievement. These motivations towards homeowning may also be prevalent among businesspersons who travel often and may not need a permanent residence

Another important drawback of this field of study is its focus on internal drives and motivation which shadows the role of the environment. The housing environment is one of the most important considerations for housing acquisition, as it is commonly held that location is the most important factor in housing, and every property in favourable locations will sell. Therefore, humanistic psychology does not appear as a suitable domain to study homeownership behavioural tendencies.

\section{Homeownership from the Social Psychology Perspective}

Social psychology is a field that attempts "to understand and explain how the thought, feeling, and behaviour of individuals are influenced by the actual, imagined, or implied presence of others" (Allport, 1985). Homeownership decisions, according to social psychology, is not a decision that can be arrived in isolation and is said to be affected by the homebuyer's social circle. Two theories explain this field, namely the Theory of Reasoned Action (TRA) and its later extension, Theory of Planned Behaviour (TPB).

The Theory of Reasoned Action (TRA) holds that an individual's own attitude and subjective norms will influence their behavioural intentions and later their actual behaviour. Attitude refers to an individual's evaluation of one's ownself while subjective norm refers to the social pressure to perform or not to perform the behaviour (Fishbein \& Ajzen, 1975; Ajzen \& Driver, 1992, p.208). The TRA is as shown in Figure 2.

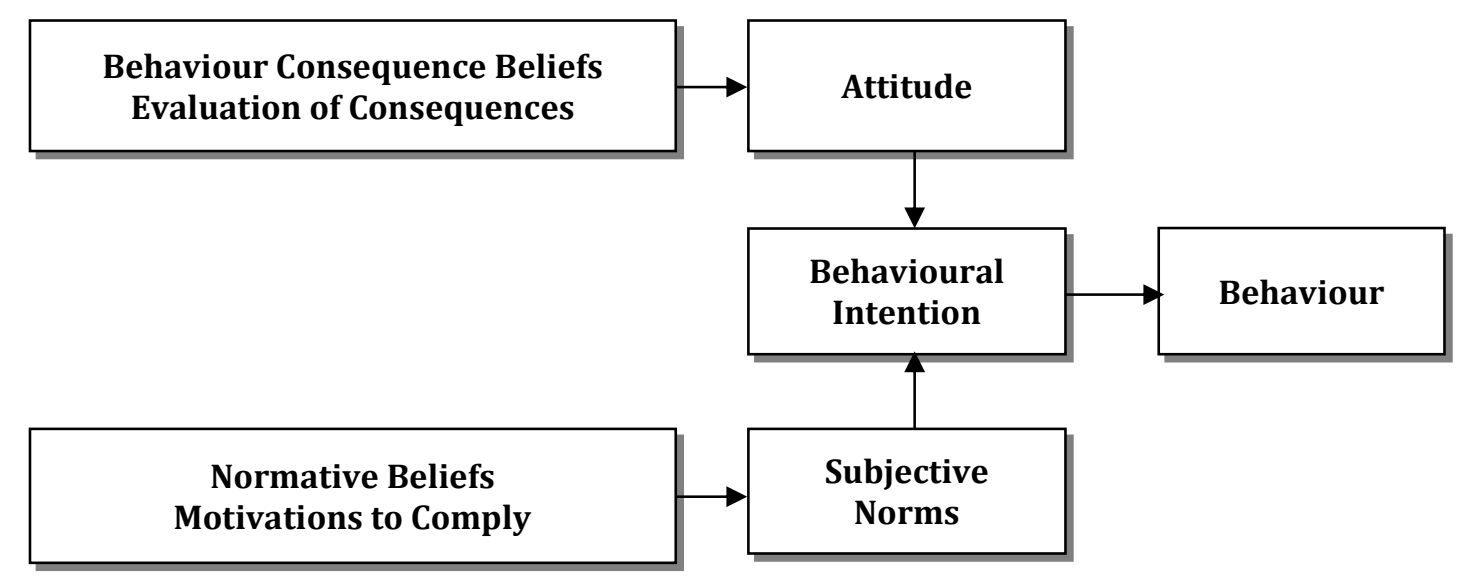

Figure 2: The Theory of Reasoned Action (1975) 
Volume 5 Issue 21 (December 2020) PP. 22-33 DOI 10.35631/IJLGC.521003

n homeownership, attitude may elaborate on individuals' own beliefs about the importance of homeownership whereas subjective norm may evaluate the influence of their social circles including friends and family on their decision. However, the TRA was still unable to assess the impacts of the environment such as location, which is an important factor in housing-related decisions.

Later the TRA was further improved by Ajzen (1985). Ajzen noted that there were imperfect conditions that may have prevented behavioural intention to manifest as actual behaviour. Therefore, the Theory of Planned Behaviour (TPB) was proposed. The TPB considers the perceived ease of performing the behaviour, or perceived behavioural control (PBC) has influence over intention and actual behaviour (Ajzen \& Driver, 1992). With the introduction of the PBC, the theory becomes more comprehensive. In the TPB, the environmental factors may be incorporated as part of the PBC to study homeownership intentions. The TPB is as shown in Figure 3.

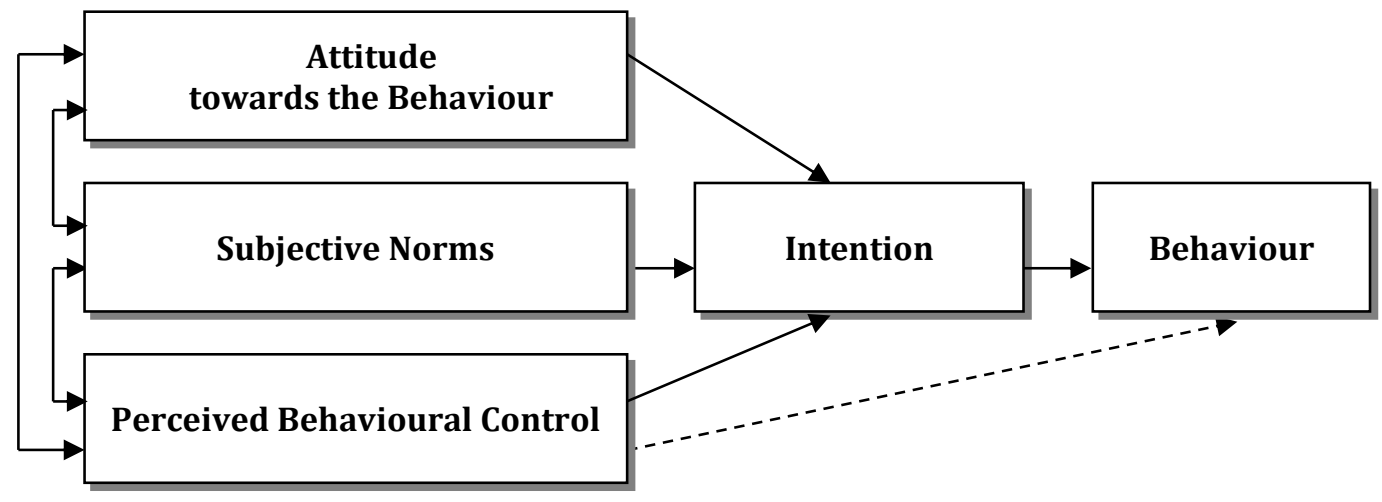

Figure 3: The Theory of Planned Behaviour (1985) 


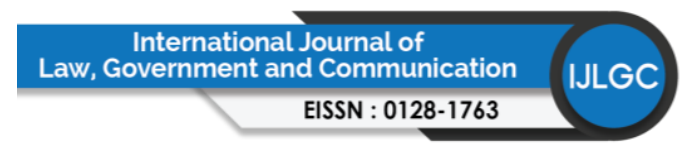

Volume 5 Issue 21 (December 2020) PP. 22-33 DOI 10.35631/IJLGC.521003

In the greater part of the past decade, the TPB has been used extensively for homeownership and also home-purchase studies (e.g. Sangkakoon et al., 2014; Karunarathne \& Ariyawaansa, 2015; Lindblad et al., 2017; Sangkakoon \& Ngarmyarn, 2017). However, this is still problematic as the studies that adapted TPB have been neo-classical methods that is more suited for macro-research (Cohen et al., 2009; Lindblad et al., 2017). Moreover, adaptations of the TPB also did not assess impacts of the environment on homeownership despite its importance. This may be because the TPB did not allow an objective assessment of the environment. In the TPB, the environment serves as a control mechanism that either facilitates or constrains behaviour, not directly producing the behaviour (Handy, 2005).

The TPB has also been criticised for being too rational, meaning it is too concerned with logic, and ignoring the many cognitive and affective processes that always bias human judgements (Geraerts et al., 2008; Conner \& Armitage, 1998; Wolff et al., 2011). In any home-acquisition decision, the process is often complicated with emotions (Levy et al., 2009; Jørgensen, 2015). Emotional responses have also appeared to be more powerful than cognitive influences in influencing one's behaviour (Morris et al., 2002) While the TPB theorises that attitude (cognitive) directly influences behavioural intention, there are studies that suggest that it would first stir emotions (an affective domain) before leading to behaviour (Morris et al., 2002; Kyle et al., 2004; Jorgensen \& Stedman, 2011).

\section{Homeownership from the Environmental Psychology Perspective}

While homeownership requires a theory that can assess the housing environment objectively, it was previously difficult because the environment is inanimate, and difficult to link with human behaviour which is animate and living. Eventually, the field of environmental psychology was conceived. Environmental psychology is a field which is "concerned with establishing and understanding the relationship between human behaviour, experience and the physical environment" (Prohansky \& Altman, 1979, p.4) was borne through attempts by urban planners to solve rising social problems in urban centres (Stokols \& Altman, 1987).

One advantage over social psychology theories is the greater emphasis given to the environment in its role in determining behaviour. It permits "an appreciation of the complexity of behaviour, including the likely operation of reciprocal, mediated, and moderated effects between variables within intricate causal networks and an insistence on clear specification and precise measurement of core constructs and processes" (Bradley \& Leser, 2017, p.32). Thus, environmental psychology establishes a firm theoretical foundation to link the environment with individuals' homeownership intentions. As discussed in the previous sub-section, emotions or affect is one of the important influencers of housing behaviour.

The Mehrabian-Russell Three-factor Theory of Emotions, or more commonly the MehrabianRussell Model (MR Model) is the most cited theory in environmental psychology. It was conceived by Albert Mehrabian and James Russell based on the Stimulus-Organism-Response (SOR) paradigm (Mehrabian \& Russell, 1974). According to Mehrabian and Russell (1974), all emotions can be represented as a combination of three emotional factors namely pleasure, arousal, and dominance, forming the emotional state of a person. Pleasure is the sense of pleasantness and contentment; arousal is the sense of excitement; and dominance is the sense of being dominating rather than dominated. The Mehrabian-Russell Model is as shown in Figure 4. 


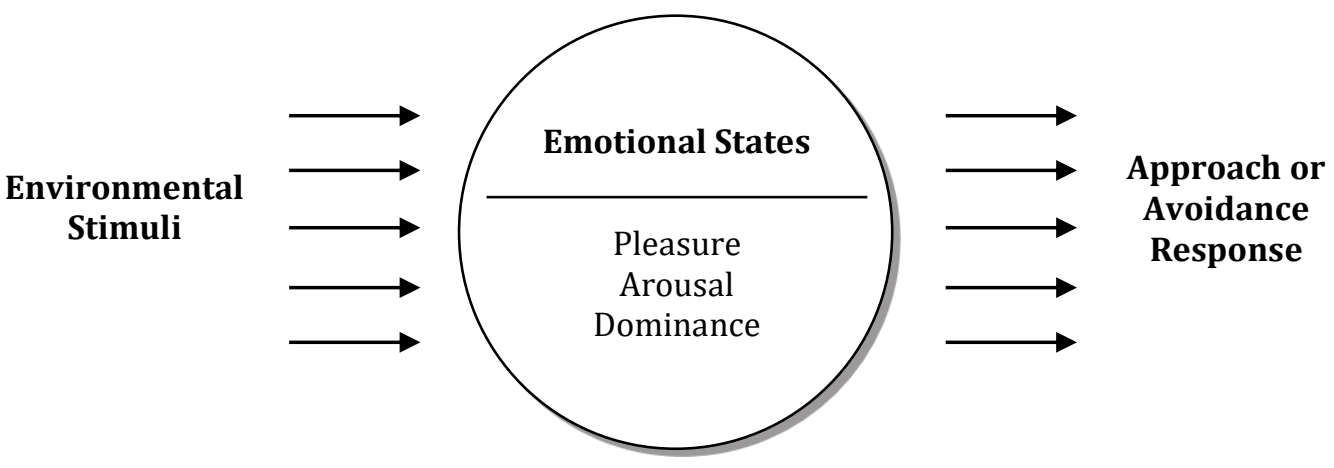

Figure 4: The Mehrabian-Russell Model of Emotions (1974)

Compared with the TRA and TPB, the MR Model allowed the role of environment to be assessed in a more objective manner (Proshansky \& Altman, 1979, Jeger \& Slotnick, 1982; Stokols \& Altman, 1987). and role of emotions (important in housing studies) to be evaluated. Various literatures (Ibem \& Alagbe, 2015; Baum, 2015; Christie et al., 2008; Jørgensen, 2015; Levy et al., 2009) acknowledge the role of emotions in housing-oriented behaviour. Ibem and Alagbe (2015) notes "the way people perceive and evaluate their residential environment is influenced by their feeling states and ability to judge the performance of the environment in relation to specific needs, aspirations and expectations" (p.471).

There were studies (Saw \& Tan, 2014; Tan \& Cheah, 2012) that found that neighbourhood environment was not significant in influencing home purchase intention. Looking at this through the environmental psychology perspective, we may attribute it to the lack of an emotional link that connects the neighbourhood setting environment with the purchase behaviour. Emotional states represent the affect component that ties the entire study together by providing a link between the inanimate nature of the residential environment and homeownership intention which is an animate nature of human behaviour.

Many studies that have adapted the MR Model has also employed other forms of emotions such as bipolar emotional dimensions whereby emotions are distinguished by polarity, being either positive or negative (Jang \& Namkung, 2009; Lee et al., 2008). There are also studies that have removed dominance (e.g. Donovan et al., 1994; Wakefield \& Baker, 1998; Eroglu et al., 2003). All these have shown the theory to be versatile and adaptable to different environmental conditions, including a housing environment.

\section{Proposed Theory and Framework}

Thorough investigation found the Mehrabian-Russell model to be most appropriate for homeownership research. To adapt the theory for housing research, the following are recommended. First, the environment dimension may be represented as the residential environment. It can be adapted to various residential environmental setting covering factors such as location, neighbourhood, home structures).

Second, for the emotional states, we propose that it may continue to be represented by Mehrabian and Russell's original three factors namely pleasure, arousal, and dominance, or the dimension may also be represented by place attachment which has been receiving growing Copyright $\odot$ GLOBAL ACADEMIC EXCELLENCE (M) SDN BHD - All rights reserved 
Volume 5 Issue 21 (December 2020) PP. 22-33 DOI 10.35631/IJLGC.521003

attention among researchers (Scannell \& Gifford, 2010). Nonetheless, we advise against using bipolar (negative versus positive emotions) because there were instances where negative emotions show more non-significant paths (Jang \& Namkung, 2009; Lee et al., 2008). Machleit and Eroglu (2000) also warned that categorising in this manner will lead to loss of information. Therefore, we advise against using it.

Third, the behavioural response dimension (approach or avoidance response) was adapted by using the two opposing tenure choices namely homeownership intention (an approach response) and leasing intentions (an avoidance response). Nonetheless, we recommend that studies should employ either one rather than both behavioural responses at the same time. The usage of the positive form of behaviour is recommended if the objectives are clear (Kashima \& Lewis, 2000; Wu et al., 2008) which is presumably why the theory recommends an approach "or" avoidance response. Having a competing negative behaviour is a bad idea unless the direction of the research is not clear.

Fourth, while the Mehrabian-Russell Model should be use as the underlying theory for housing research, it still lacks the individual attitudinal element that defines individual motivations in homeownership. Therefore, the theory of Planned Behaviour is proposed as the complementing theory. Although the TPB holds that these factors (cognitive) have a direct impact on behavioural intention, there are suggestions that they will first influence the affective component before influencing behaviour (Morris et al., 2002; Kyle et al., 2004; Jorgensen \& Stedman, 2011). Hence it is included in the framework. Figure 5 shows the conceptual framework to assess the determinants of homeownership or leasing intentions.

Environmental Factors

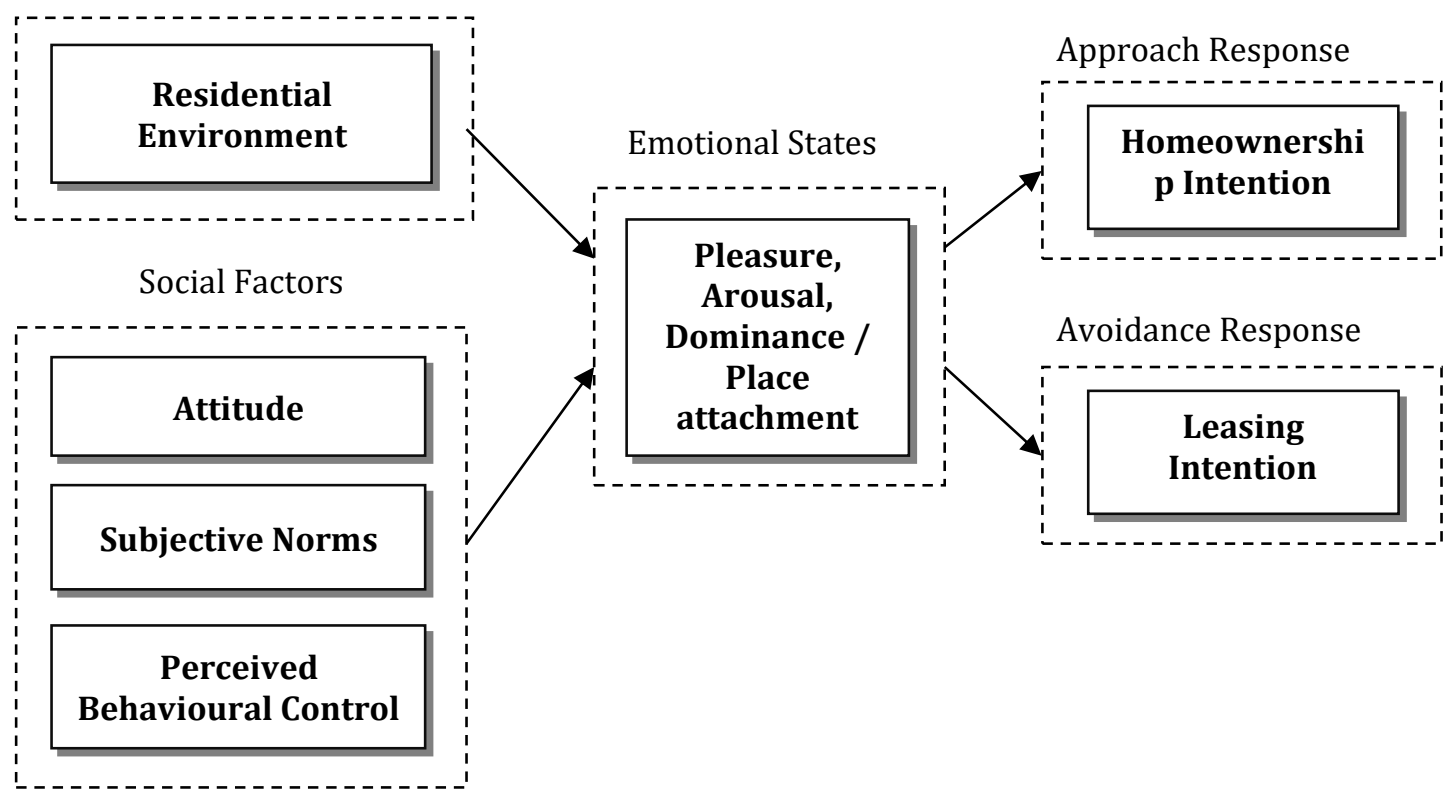

Figure 5: Proposed Framework 


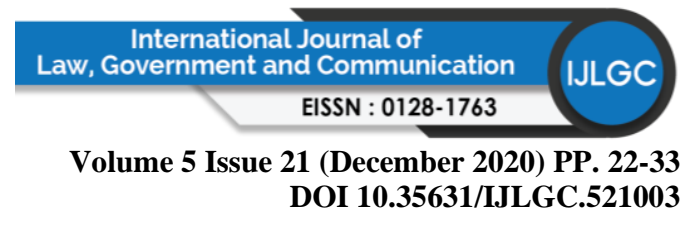

\section{Conclusion}

In summary, the review found that the Mehrabian and Russell's (1974) Theory of Emotions to be suitable for the study of homeownership and leasing intentions. However due to the importance of attitudinal factors from the TPB as highlighted in previous research, they are included to complement the vacuum in the MR Model. The proposed framework consists of four dimensions: (i) environmental factors: this comprises of elements of the residential estate or living quarters. This may include structural factors like built up, number of bedrooms, bathrooms, garden space; (ii) social factors: this comprises of personal, attitudinal factors and may traditionally be represented using elements from the Theory of Planned Behaviour namely attitude subjective norms, perceived and actual behavioural controls; (iii) emotional states: the emotional responses towards the prospects of homeownership which may be represented using Mehrabian and Russell's three emotional factors namely pleasure, arousal and dominance. Finally (iv), approach or avoidance response: this comprises of either the intentions to own a home (favourable / approach response) or intention to lease a home (unfavourable / avoidance response). It is posited that social and environmental factors will affect changes in approach or avoidance response through the mediation of emotional states.

\section{References}

Ajzen, I. (1985). From Intentions to Actions: A theory of planned behavior. In J. Kuhl\& J. Beckman (Eds.), Action-control: from Cognition to Behaviour (pp. 11-39). Heidelberg, Germany: Springer.

Ajzen, I. and Driver, B. L. (1992). Application of theory of planned behaviour to leisure choice. Journal of Leisure Research, 24(3), 207-224.

Ajzen, I. and Fishbein, M. (2005). The influence of attitudes on behaviour. In D. Albarracín, B. T. Johnson, and M. P. Zanna (Eds.), The handbook of Attitudes (pp. 173-221). New Jersey: Lawrence Erbaum.

Allport, G. W. (1985). The historical background of social psychology. In G. Lindzey and E. Aronson, (Eds.), Handbook of Social Psychology, (pp. 1-46). New York: Random House.

Baum, H. (2015). Planning with half a mind: Why planners resist emotion. Planning Theory \& Practice, 16(4), 498-516.

Boelhouwer, P. \& Dol, K. (2011). Economic crisis and the impact on Western European countries, The impact of Housing and Planning on the Economic Environment, Estonia: International Federation for Housing and Planning.

Bourguignon, F., Browning, M., Chiappori, P. A., \& Lechene, V. (1993). Intra household allocation of consumption: A model and some evidence from French data, Annalesd' Economieet de Statistique, 137-156.

Bradley, G. L., \& Reser, J. P. (2017). Adaptation processes in the context of climate change: a social and environmental psychology perspective. Journal of Bioeconomics, 19(1), 2951.

Christie, H., Smith, S. J. \& Munro, M. (2008). The emotional economy of housing. Environment and Planning A, 40, 2296-2312.

Cohen, T. R., Lindblad, M. R., Paik, J. G., and Quercia, R. G. (2009). Renting to owning: An exploration of the theory of planned behavior in the homeownership domain. Basic and Applied Social Psychology, 31(4), 376-389.

Conner, M. \& Armitage, C.J. (1998). Extending the theory of planned behavior: A review and avenues for further research. Journal of Applied Social Psychology, 28, 1429-1464. 


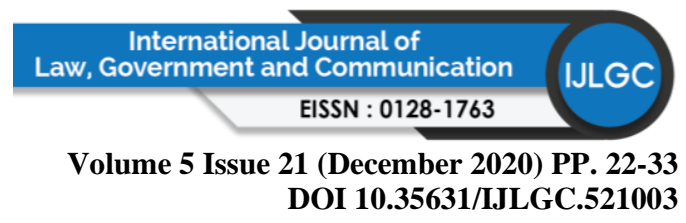

Darley, J. M., \& Gilbert, D. T. (1985). Social psychological aspects of environmental psychology. Handbook of social psychology, 2, 949-992.

DeYoung, R., \& Rice, T. (2004). Noninterest income and financial performance at US commercial banks. Financial Review, 39(1), 101-127.

Donovan, R. J., Rossiter, J. R., Marcoolyn, G., \& Nesdale, A. (1994). Store Atmosphere and Purchasing Behavior. Journal of Retailing, 70(3), 283-294.

Eroglu, S. A., Machleit, K. A., \& Davis, L. M. (2003). Empirical testing of a model of online store atmospherics and shopper responses. Psychology \& Marketing, 20(2), 139-150.

Fishbein, M., \& Ajzen, I. (1975). Belief, attitude, intention, and behavior: An introduction to theory and research. Reading, Massachusetts: Addison-Wesley.

Geraerts, E., Bernstein, D.M., Merckelbach, H., Linders, C., Raymaeckers, L. and Loftus, E. F. (2008). Lasting false beliefs and their behavioral consequences. Psychological Science, 19, 749-753.

Gervais, M. (2002). Housing taxation and capital accumulation, Journal of Monetary Economics, 49(7), 1461-1489.

Handy, S. (2005). Critical assessment of the literature on the Rrelationships among transportation, land use and physical activity. In Does the Built Environment Influence Physical Activity? Examining the Evidence. Resource Paper for TRB Special Report 282.

Ibem, E. O., \& Alagbe, O. A. (2015). Investigating dimensions of housing adequacy evaluation by Residents in public housing: Factor analysis approach. Facilities, 33(7/8), 465-484.

Jang, S. C., \& Namkung, Y. (2009). Perceived Quality, Emotions, and Behavioural Intentions: Application of an Extended Mehrabian-Russell Model to Restaurants. Journal of Business Research, 62(4), 451-460.

Jeger, A. M., \& Slotnick, R. S. (1982). Community mental health. In Community Mental Health and Behavioral Ecology (pp. 7-26). Boston, Massachusetts: Springer.

Jorgensen, B. S. \& Stedman, R. C. (2001). Sense of place as an attitude: Lakeshore owners attitudes toward their properties. Journal of environmental psychology, 21(3), 233-248.

Jørgensen, C. J. (2015). The space of the family: Emotions, economy and materiality in homeownership. Housing, Theory and Society, 33(1), 1651-2278

Karunarathne L., \& Ariyawansa, R. G. (2015). Analysis of house purchase intention. Sri Lankan Journal of Management, 20(3/4), 28-51.

Kashima, Y. \& Lewis, V. (2000). Where does the behaviour come from in attitude-behaviour relations? Towards a connectionist model of behaviour generation. In M. A. Hogg \& D. J. Terry (Eds.). Attitudes, Behaviour and Social Context: the Role of Norms and Group Membership. New Jersey: Lawrence Erlbaum.

Karunarathne L., \& Ariyawansa, R. G. (2015). Analysis of house purchase intention.

Kokoszka, A. (1991). On the psychology of experiencing values: A supplement to the evolutionary level model of the main states of consciousness. Imagination, Cognition and Personality, 11(1), 75-84.

Kyle, G., Graefe, A., Manning, R., \& Bacon, J. (2004). Effects of place attachment on users' perceptions of social and environmental conditions in a natural setting. Journal of Environmental Psychology, 24(2), 213-225.

Lee, J. (2002) Is there an East Asian housing culture? Contrasting housing systems of Hong Kong, Singapore, Taiwan and South Korea. In European Network for Housing Research Conference, Vienna University.

Lee, Y. K., Lee, C. K., Lee, S. K. \& Babin, B. J. (2008). Festivalscapes and patrons' emotions, satisfaction, and loyalty. Journal of Business Research, 61(1), 56-64.

Copyright $\odot$ GLOBAL ACADEMIC EXCELLENCE (M) SDN BHD - All rights reserved 


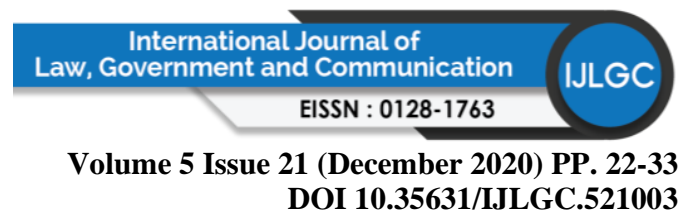

Levy, D., L. Murphy, \& C. K. C. Lee. 2009. Influences and emotions: Exploring family decision making processes when buying a house.” In S. J. Smith \& M. Munro (Eds.), The Microstructures of Housing Markets (pp. 110-128). Abingdon: Routledge.

Lindamood, S., \& Hanna, S. D. (1979). Housing, Society, and Consumers. Minnesota: West Publishing Company.

Lindblad, M. R., Han, H. S., Yu, S. \& Rohe, W. M. (2017). First-time homebuying: attitudes and behaviors of low-income renters through the financial crisis. Housing Studies, 32(8), 1127-1155.

Machleit, K. A., Eroglu, S. A., \& Mantel, S. P. (2000). Perceived retail crowding and shopping satisfaction: what modifies this relationship?. Journal of Consumer Psychology, 9(1), $29-42$.

Marsh, A., \& Gibb, K. (2011). Uncertainty, expectations and behavioural aspects of housing market choices. Housing, Theory and Society, 28(3), 215-235.

Maslow, A. H. (1954). Motivation and Personality. New York: Harper \& Brothers

Mehrabian, A. \& Russell, J. A. (1974). An Approach to Environmental Psychology. Cambridge, Massachusetts: MIT Press.

Morris, J. D., Woo, C., Geason, J. A. \& Kim, J. (2002). The power of affect: Predicting intention. Journal of Advertising Research, 42(3), 7-17.

Proshansky, H., \& Altman, I. (1979). Overview of the field. In W. P. White (Ed.), Resources in Environment and Behaviour (pp. 3-36). Washington: American Psychological Association.

Rohe, W. M., Van Zandt, S., \& McCarthy, G. (2013). The social benefits and costs of homeownership: A critical assessment of the research: From low income homeownership: Examining the unexamined goal, The Affordable Housing Reader, 196-213.

Ronald, R. (2007). Comparing homeowner societies: Can we construct an east-west model? Housing Studies, 22(4), 473-493.

Sangkakoon, P. \& Ngamyarn, A. (2017) Factors that affect the intention to buy a family home. (2017). Journal of Business, Economics and Communications, 12(2), 145-160.

Sangkakoon, P., Ngarmyarn, A., \& Panichpathom, S. (2014) The influence of group references in home purchase intention in Thailand. In 21st Annual European Real Estate Society Conference, Bucharest, Romania.

Saw, L. S., \& Tan, T H. (2014). Factors affecting the purchase decision of investors in the residential property market in Malaysia, Journal of Surveying, Construction and Property, 5(2), 1-13.

Scannell, L. \& Gifford, R. (2010). Defining place attachment: A tripartite organizing framework. Journal of environmental psychology, 30(1), 1-10.

Stokols, D., \& Altman, I. (1987). Handbook of Environmental Psychology. New York: John Wiley and Sons.

Tan, T. H. (2008). Determinants of homeownership in Malaysia. Habitat International, 32(3), 318-335.

Tan, T. H., \& Cheah (2012). Locational, neighbourhood, structural and socio-cultural attributes of housing in homeownership decisions. In International Real Estate Symposium (IRERS) 2012: Globalization of Real Estate: Transforming and Opportunities, National Institute of Valuation.

Van Ham, M. (2012). Housing behaviour. In D. F. Clapham, W. A. V. Clark \& K. Gibb (Eds.). The SAGE Handbook of Housing Studies (pp. 47-65). London: Sage Publishing. 
Volume 5 Issue 21 (December 2020) PP. 22-33 DOI 10.35631/IJLGC.521003

Wahba, M. A. \& Bridwell, L. G. (1976). Maslow Reconsidered: A Review on the Need Hierarchy Theory. Organizational Behaviour and Human Performance. 15(2), 212240.

Wolff, K., Nordin, K., Brun, W., Berglund, G. \& Kvale, G. (2011). Affective and cognitive attitudes, uncertainty avoidance and intention to obtain genetic testing: An extension of the theory of planned behaviour. Psychology and Health, 26, 1143-1155.

Wakefield, K. L., \& Baker, J. (1998). Excitement at the mall: Determinants and Effects on Shopping Response, Journal of Retailing, 74(4), 515-539.

Wu, C. S., Cheng, F. F., \& Yen, D. C. (2008). The Atmospheric Factors of Online Storefront Environment Design An Empirical Experiment in Taiwan, Information \& Management, 45(7), 493-498.

Yun, L. \& Evangelou, N. (2016). Social Benefits of Homeownership and Stable Housing. Washington: National Association of Realtors

Zavei, S. J. A. P. \& Jusan, M. M. (2012). Exploring housing attributes selection based on Maslow's hierarchy of needs. Procedia-Social and Behavioural Sciences, 42, 311-319. 